doi: $10.19090 /$ i.2017.28.86-104

UDC: 94(497):355.48(497.127 Mohács)

ATTILA PFEIFFER

University of Novi Sad, Faculty of Philosophy, Department of History

attilapfeiffer@ff.uns.ac.rs

\title{
THE BATTLE OF CHRISTIANS AND OTTOMANS IN THE SOUTHWEST OF BAČKA FROM THE BATTLE OF MOHÁCS TO THE PEACE OF ZSITVATOROK
}

\begin{abstract}
After the battle of Mohács in 1526 the medieval kingdom of Hungary was torn into three parts. The middle part from Buda to Belgrade was under the rule of the Ottoman Empire. These territories suffered much in the 16th century because of the wars between the Habsburgs and the Ottoman Turks. Therefore, we do not have many historical resources from this period. The territory of South Bačka was a war zone many times from 1526 to 1606, where the Habsburgs, Hungarians and Ottoman Turks fought many battles. The aim of this study is to represent these struggles between Christians and Muslim Turks, focusing on the territories of the early modern Counties of Bač and Bodrog. Moreover, we are going to analyse the consequences of these wars for the population and economy of the mentioned counties.
\end{abstract}

Keywords: early modern period, Ottoman Hungary, Counties of Bač and Bodrog, fortress of Bač, Turkish wars, military history.

A fter the defeat of the Hungarian army on the field of Mohács (29 August 1526), Hungary went through perhaps the worst period in its history. Simultaneously it had to fight against the conquerors and in the meantime, the issue of the heir to the throne was raised because of the death of king Lajos II (1516-1526) in the battle of Mohács. Hungary was divided regarding the question of who would be the new king in the kingdom. While the great magnates and nobility in the north and the west chose the Archduke Ferdinand I (1526-1564) to be the king, Hungarian nobles in the central and eastern parts of the country chose the Duke of Transylvania (Erdély) János Szapolyai (1526-1540). However, a bigger problem was that in the next two centuries Hungary was a battlefield between the Ottoman Empire and the Habsburg Monarchy. ${ }^{1}$

After the battle of Mohács, Suleiman the Magnificent (1520-1566) rested with the Ottoman army and afterwards he headed to Buda. ${ }^{2}$ On 9 September 1526, the Ottoman

\footnotetext{
${ }^{1}$ Pállfy 2009: 10.

${ }^{2}$ Katona 1976: 167.
} 
sultan entered the capital of medieval Hungary without resistance ${ }^{3}$ while the court fled to Bratislava (Pozsony) with Queen Mary. ${ }^{4}$ Suleiman burned down Pest on 25 September and after that he divided his army into two parts and the armies moved south. The Sultan himself advanced along the Danube to the south, while the great vizier Ibrahim, ${ }^{5}$ who had strong cavalry, headed towards Szeged and the two armies were supposed to meet and reunite again at Petrovaradin (Pétervárad). The army of the great vizier Ibrahim robbed and burned Kecskemet on 27 September and continued towards Szeged. The Great Vizier wanted to clash with Szapolyai's army near the city of Szeged, but he found an empty city and devastated surroundings. ${ }^{6}$ Ibrahim robbed Szeged and continued his way to the south. ${ }^{7}$ One company of the great Vizier besieged Subotica, but the nobility, citizens and inhabitants of the surrounding villages who sought refuge in the city bravely fought and defended the city. ${ }^{8}$ The Great Vizier could not provide help because of weather conditions and because of the fear of Szapolyai's army that was nearby, according to reports of Ottoman spies. Subotica was rescued, but Ibrahim's army took Senta (Zenta), Perlek, Pačir (Pacsér) and Kanjiža (Magyarkanizsa). ${ }^{9}$

The population between the Danube and the Tisza already knew a little bit more about the way the Ottomans were waging warfare than those who lived across the Danube and that is precisely why whoever could escape on time did that. However, the population of Bačka was already surrounded by the Ottoman army. ${ }^{10}$ The Ottoman flag fluttered on the southern fortresses and the Sultan's and the Great Vizier's armies were approaching from the north. This trap forced the population to try a hopeless resistance, first in Bač (Bács) and further south in an unknown trench. ${ }^{11}$ The Great Vizier was constantly informed by his spies about the movement of the Sultan's army. This is how Ibrahim learned near Szeged that Suleiman's army was already at the fortress of Bač, so he continued his way south towards Titel. ${ }^{12}$ In the meantime, after occupying Baja, where a Franciscan monastery also became a victim, Suleiman's army continued towards Bački Monoštor (Bodrogmonostor), ${ }^{13}$ which was burned down. From Monoštor the army moved towards Bač. Even before the

\footnotetext{
${ }^{3}$ Szakály 1990: 114 .

${ }^{4}$ B. Szabó 2006: 93.

${ }^{5}$ Pargali Ibrahim pasha was born in 1493 on the island of Parga and was killed on 15 March 1536 in Istanbul. During the rule of Suleiman the Magnificent he was the Grand Vizier between 1532 and 1536. He became the sultan's brother in law when he married his sister, widow Hatice, and he was the commanding officer of many quests initiated by Suleiman. He played an important role in occupying Rhodes and Belgrade, as well as in the Battle of Mohács. During his thirteen years as a grand vizier, he became very rich and powerful, which many people in the Ottoman empire disliked. In the end, his fall was triggered by intrigues of a former slave, initiated by the powerful sultan Hürrem.

${ }^{6}$ Rokay, Györe, Pál, Kasaš 2002: 163.

${ }^{7}$ Barta 1983: 16.

${ }^{8}$ Reiszig 1909: 91.

${ }^{9}$ Barta 1983: 16-17.

${ }^{10}$ Dudás 1896: 108-110.

${ }^{11}$ Reiszig 1909: 92.

${ }^{12}$ The town of Titel is located in the Titel plain in southeast Bačka, on the right bank of the Tisza river. Across the river on the Banat side, the river Bega flows into the Tisza and a few miles downstream the Tisza flows into the Danube.

${ }^{13}$ Present-day Bački Monoštor, located about 10 km northwest of Sombor, not far from the Danube.
} 
battle of Mohács, the population of the town clashed with one Ottoman troop of robbers after the fall of Petrovaradin (27 July 1526), who wanted to "catch tongues" 14 in Bač. ${ }^{15}$ Although the population of Bač offered strong resistance, according to the tradition of contemporary Ottoman historians, the city fell into the hands of conquerors. During the siege, the Christian population sought refuge in the Franciscan church, which, according to Mustafa bin Dzelal, ${ }^{16}$ was as large as a fort. The church was defended by Christians for quite a long time because they had plenty of guns and gunpowder; however, the Turkish army fired at the church with cannons until it was completely demolished and all of its defenders were killed. The Turkish army led many prisoners into captivity and gained a rich prey. In the vicinity of the city there were many sheep, so 50,000 were given to a pasha (not specified which one), while 20,000 were given to İskender Çelebi, a Turkish defterdar ${ }^{17}$. Mustafa bin Dzelal wrote about these events as follows:

Near the bank of the Danube there was a town called Bač, which was a great city of the beaten king; it had one big church devoted to the devil, which was full of idols of these spawns of hell. A happy army robbed this place, which became part of hell, of all the population the army killed the men, while many women were captured and the loot was endless. Nearly all the people were locked up in that church, which was as big as a fortress. The captured dogs fought until the asr prayer ${ }^{18}$ with a victorious army and since the cursed people had rifles inside, many Muslims became martyrs, but after the asr prayer the gates of victory opened: soldiers destroyed this church and captured many prisoners and boundless plunder. ${ }^{19}$

The Turkish chronicler Kemalpaşazâde also wrote about the siege and plunder of the town of Bač. ${ }^{20}$ Here we can read how Suleiman took over the city:

\begin{abstract}
Along the way, across the mountains and valleys, in the gardens and granges, like bloodthirsty dogs and wolves, catching the spawns of hell like lions, leaving nothing for the evil of the natural enemy, no plains, no houses on the mountains, no fields, their own property and the grain necessary for their existence mercilessly destroyed, he reached a mighty fortress, whose towers faced the sun and reached
\end{abstract}

14 "To catch tongues" during the Turkish conquest meant to catch a prisoner of war. Fort captains tried to catch as many "tongues" as possible. Knights usually rode until they caught prisoners. The "tongue" could be a soldier or an inhabitant of an occupied territory. Afterwards they would force them to "loosen their tongues," i.e. to give relevant information about the enemy. If they did not want to speak, they would be tortured.

${ }^{15}$ Sekulić 1978: 45.

${ }^{16}$ Mustafa bin Dzelal was born at the end of the $15^{\text {th }}$ century in Asia Minor and already in 1520 he was one of the scribes of the divan and between 1521 and 1525 he was the grand vizier's scribe. From 1525 to 1534 he was a Reis Efendi or Reis ül- Küttab, who was a senior post in the administration of the Ottoman Empire. The holder of the post was originally the head of the chancery of the Imperial council. Between 1534 and 1557 and from 1566 to 1567 he was a secretary of the divan. He died in 1567 . Because of his high position he participated in many quests of the Ottoman Empire and held first-hand information. He was well acquainted with the Ottoman laws. His most important work was "State classes and road enumeration."

${ }^{17}$ Turkish tax collector.

${ }^{18}$ The time of day between noon and sunset, the time of the third prayer.

19 Thúry 1896: 170.

20 Kemalpaşazâde or Şemseddin Ahmet ibn Süleyman ibn Kemal Paşa was born in Edrine in 1483. He was educated for a military career but he devoted his life to science. Since 1526 he was a Sheikh ul-Islam, i.e. the supreme religious dignitary, the leader of the knowers of the laws, judges, imams and teachers. He died in 1524. One of his most important works was Mohacsname, which was about the quest against Hungary in 1526. 
towards the sky, which was known by the people under the name Bač. In this fortress, which was erected on a stone foundation, the captured villains felt secure and they did not fear robbery or being conquered by any enemy. Its foundations lay at the bottom of water, its towers were lost in the clouds. The Sultan and his army arrived like a restless sea, he camped nearby... When the unconquerable army surrounded the high walls, the captain of the fort, the wali ${ }^{21}$ of this province and the population of the city sought the mercy of the Sultan so that his wrath would not take their lives, their houses, their properties and their families. In their last request they prayed for grace to save their lives, so they escaped to become slaves. After the fortress, this old refuge of godlessness was surrendered to the servants of the great Sultan with weapons and other war materials, they themselves, with tears in their eyes and bare heads, only wearing the clothes on their back, left the fortress and surrendered all the possessions to the conquerors. The cannons and other warfare that was left behind were seized. Afterwards they robbed the markets and the streets. After scraping the flowers out of the garden and picking fruit from trees, they burned down the houses. This city, which until recently appeared to be a beautiful garden of roses, had now become a burning furnace, whose smoke flew towards the blue sky. ${ }^{22}$

After Suleiman conquered and robbed Bač, he continued towards the south where he encountered unexpected resistance. Between Bač and Futog (Futak), near Plavna (Palona), which was protected by marshes and bogs, the Turks had a tough battle. In this camp, many sought refuge from the Ottomans. Only on 6 October did the Sultan succeed in defeating this camp of horse carriages after losing a large number of soldiers. The defenders did not surrender even when the Turks penetrated the defensive line of Christians. Even the Ottoman chroniclers admitted that the infidels fought bravely against the Turks - they resolutely fought for their women and children. ${ }^{23}$ In the ranks of the attackers, besides the ordinary soldiers the janissary aghas, several officers and sipahi were also killed. ${ }^{24}$ The Sultan did not think he would face such a strong resistance. That is why he ordered all the survivors in the camp to be executed and he went on to Vašaroš Varad, ${ }^{25}$ where he arrived on 8 October. ${ }^{26}$

In the meanwhile, Ibrahim's army arrived in front of the Titel fort on 2 October. The fortress was well-supplied with weapons and food, but when the garrison of the fortress heard that the Ottoman army was approaching, they retreated leaving the fortress empty so the army of the great vizier entered without resistance on 2 October. Taking Titel without resistance surprised Suleiman as the Ottoman army commanders said they were preparing for a longer siege ${ }^{27}$ Contemporary Turkish historians especially highlight the strategic position of the fortress. According to Ferdi/Bostan, ${ }^{28}$ the walls of the fortress looked like hard rock and towers like large iron wardrobes. "Meanwhile, the infidels surrendered with concern the strong fortress of Titel, where the waters of the river Tisza flow into the Danube,

${ }^{21}$ Turkish name, an adequate equivalent would be 'governor.'

22 Thúry 1893: 272-273.

${ }^{23} \mathrm{Ibid} .268$.

${ }^{24}$ R. Várkonyi 1987: 153.

${ }^{25}$ Present-day city of Novi Sad.

${ }^{26}$ Barta 1983: 18-19.

${ }^{27}$ Reiszig 1909: 92.

${ }^{28}$ We know very little on Ferdi Efendi/Bostan, only the things we can guess from his works. He lived during the reign of Suleiman the Magnificent, he wrote poems, and he was most likely a clerk of the divan. His work "History of Suleiman the Lawmaker" describes the events between 1520 and 1542. 
whose walls look like hard rock and towers like large iron wardrobes, that is, the strong fort of Bač on the bank of the Danube."29

However, the joy of Ottoman soldiers was not complete because the rear part of the Turkish army was suddenly attacked by the leader of the šajkaš ${ }^{30}$ Radić Božić, killed 500 soldiers and captured $400 .{ }^{31}$ After Ibrahim conquered Titel, he set up a crew, gave his soldiers leave and headed for Petrovaradin. On 3 October he arrived on the territory of the present-day Novi Sad, where he set up his camp. Here he waited for Suleiman, who was coming from the direction of Bač. ${ }^{32}$ The population ran away from the enemy. Modern Turkish chroniclers wrote that their army was passing through the desolate lands and villages. Apart from Subotica, Bač and Plavna, they did not face resistance anywhere else. ${ }^{33}$

Ibrahim was already waiting for his ruler near Petrovaradin. Suleiman spent two days in Ibrahim's camp and, after the bridge was completed on 9 October, his army began crossing the Danube. The next day the sultan entered Petrovaradin, reconstructed the fortress, and on 11 October he continued towards Belgrade. At the beginning of October, the Turks left Hungary and the crews remained only in those Danube fortresses that they occupied during the summer of the previous year. A large part of Srem had already fallen under the rule of the Ottomans by then. This is how the southern defensive line of Hungary disappeared and it was open to the Turks. ${ }^{34}$ On 11 October the Turkish army arrived in Belgrade and began selling prisoners. The Sultan returned to Istanbul with the most precious spoils, where he arrived on 22 November. ${ }^{35}$ While he was still in Petrovaradin Suleiman ordered that the forts of Petrovaradin and Ilok (Újlak) be given crews. However, it is interesting that the Ottomans did not leave crews in a series of fortresses, such as e.g. Slankamen (Zalánkemén), Zemun (Zimony), Bač, Osijek (Eszék), Vukovar (Valkóvár), and Erdut (Erdőd). It is even more interesting that the Hungarian army returned only to Bač, while the other fortresses were empty until the spring of $1527 .{ }^{36}$

\section{Bač and the surroundings between 1527 and 1541}

After the Ottoman campaign from 1526, the damage and devastation that the conquerors left behind was clear. The county of Bačka, which was densely populated and economically rich, became a "desert." 37 Sultan Suleiman's diary and the work of Kemalpaşazâde Mohacname describe the devastation in the county. Turkish historians also mention unspeakable cruelty of the conquerors. In Kemalpaşazâde's work we can read the

\footnotetext{
${ }^{29}$ Thúry 1896: 73.

${ }^{30}$ Šajkaš (Hung. csajkás - naszád) was a small war ship (23-24 meters long and 4-5 meters wide). These ships were the Danube fleet of Hungary since the $15^{\text {th }}$ century and after the battle of Mohács they served the rulers of Hungary. They were mostly operated by Serbs and Hungarians, who had a special status as soldiers.

${ }^{31}$ Barta 1983: 19.

${ }^{32}$ Érdújhelyi 1909: 238-239.

${ }^{33}$ Reiszig 1909: 92-93.

${ }^{34}$ R. Várkonyi 1987: 155.

${ }^{35}$ Barta 1983: 19.

${ }^{36}$ Ibid. 19-20.

${ }^{37}$ Györe 2014: 120.
} 
following passage:

In addition to the city of Szeged, the mentioned region, which was called the Bačka County and was known for its fortresses, towns, villages and arable land, was conquered by the world conquerors. The trees of happiness with the roots of the poor Hungarians were pulled out by the powerful hand of the famous pasha, which was the unbreakable tower of the power of a happy and famous Sultan. ${ }^{38}$

After the Ottoman army retreated in the autumn of 1526, there were no serious clashes between Christians and Ottomans, only a few minor conflicts on the territory of Srem. The Turks besieged the Fortress of Marot and on the other side fought Radić Božić and Stevan Berislavić, or Jovan (the Black Man), who had previously sought refuge from the Turks in Hungary. The real name of Jovan was Nenad Crnojević and he was called "the Black Man" because he supposedly had one black stripe from his left eye to his foot. ${ }^{39}$ By occupation he was a horse groom of King Jovan, but the Serbian people in the territory of Hungary thought that he was a descendant of Serbian despots so they called him an emperor. ${ }^{40}$ The charismatic appearance and decisive struggle of Jovan Crnojević against the Turks won the majority of Serbs between the Danube and the Tisza. He announced that he would break the power of the Muslims and, as the successor to Serbian despots, would restore the Serbian medieval state. In these difficult times people were looking for a saviour and many thought that Jovan was a prophet and massively gathered under his flag. In a short time, Jovan possessed an army that he could count on. ${ }^{41}$

In the meantime, János Szapolyai was elected king at the state assembly in Székesfehérvár and the noblemen bowed before him one by one. He was worshiped by Valentin Terek (Török Bálint), the master of Subotica at the time, by Radić Božić, the leader of the $\check{s} a j k a s ̌$, and the emperor Jovan Nenad who later personally went to see Szapolyai and recognized him as his king. ${ }^{42}$ The king gave him horses, weapons, money and entrusted him with the desolate Bačka County, where his people could get food and at the same time represented a serious military force in the neighbourhood of the Turks. ${ }^{43}$ The "Black Man" was also supported by the court priest of King Jovan Đurađ Sremac, who in his work mentioned the donation of King Jovan for Jovan Crnojević ad desolatam terram Bácsmegye. ${ }^{44}$ Thanks to Szapolyai in the autumn of 1526 Jovan took possession of the Bačka County, whose rich pastures were ideal for Serbs who inhabited vacant territories. ${ }^{45}$ However, Emperor Jovan sided with Ferdinand of Habsburg in February 1527. In order to show his loyalty to his new king he started destroying the estate of the noblemen along the Tisza and thus king Szapolyai lost his power in Bačka instantaneously. ${ }^{46}$ On the one hand,

\footnotetext{
${ }^{38}$ Thúry 1896: 296.

${ }^{39}$ Ćirković 1982: 481-484.

${ }^{40}$ Stojkovski 2007: 150.

${ }^{41}$ R. Várkonyi 1987: 171.

${ }^{42}$ Reiszig 1909: 94.

${ }^{43}$ R. Várkonyi 1987: 171.

${ }^{44}$ Georgii Sirmiensis, Epistola de perditioneregni Hungarorum, 75.; Serbian translation: Đurađ Sremac, Poslanica o propasti Ugarskog kraljevstva, 75.

${ }^{45}$ Györe 2014: 122. Dávid 1997: 141-171, Dávid 2005: 19-20.

${ }^{46}$ Stojkovski 2007: 155.
} 
he lost the support of emperor Jovan and the šajkaš, while on the other hand, Valentin Terek sided with Ferdinand. ${ }^{47}$

In the civil war that ensued between Szapolyai and Ferdinand in 1528, Ferdinand was winning and king Jovan was pushed to the east of the country. Due to a series of defeats Szapolyai decided to establish an alliance with Suleiman in Istanbul in $1528 .{ }^{48}$ The alliance was concluded and Mehmed bey with his army camped in the Bačka and Bodroška Counties as early as January 1529. He managed to occupy the fortresses of Félegyháza ${ }^{49}$ and Bač after the betrayal. Pavle Bakić, who set up his camp near Mohács, sent a message to Buda that the people of the despot Stevan Berislavić betrayed these fortresses to the Ottomans and thus opened up the path to Pest for Turks both on the mainland and on the river:

Post humillimam seruitutis mee commendationem, Litere que nunc A Paulo Bakyth sunt allate reddentur Maiestati vestre, ex quibus intelligent Arces Bachiensem et Feleghaz que sole illis in partibus supererant, per deditionem seruitorum Domini Despoti ad Manus Turcarum peruenisse.... ${ }^{50}$

After the unsuccessful quest to Vienna in 1529, Suleiman returned along the Danube to Istanbul. On 4 November he was at Bač ${ }^{51}$ and on 5 and 6 November the Turkish army crossed the Danube on the bridge near Petrovaradin. ${ }^{52}$ After this campaign, the county of Bačka fell under the rule of János Szapolyai, as well as the fortress of Bačka, which the Turks probably returned to Szapolyai at the time..$^{53}$

The outcome of the devastation of Bačka was that the Serbian population in the county was growing. ${ }^{54}$ Already at that time they represented a serious factor between the Danube and the Tisza. The town of Bač was still under the jurisdiction of the Archbishop of

\footnotetext{
${ }^{47}$ Reiszig 1909: 94.

${ }^{48}$ R. Várkonyi 1987: 172.

${ }^{49}$ Historians and archaeologists are still not able to locate this fort. Csánki Dezső claims that Félegyháza was in the neighbourhood of Doroslovo (Doroszló) and Sonta ( western Bačka). Iványi says that this settlement existed between Bač and Bukin. It is interesting that neither Csánki nor Iványi mention the fort in Félegyháza. Csánki II 1894: 149, Iványi I 1909: 65.

${ }^{50}$ Gévay 1840: 58.

${ }^{51}$ Many historians disagree about when the fort in Bač came under the Turkish administration. At the beginning of the last century Ede Reiszig and Jene Szentkláray both believed that Turks took Bač in 1529 and their opinion was shared by Olga Zirojević. In the second half of the $20^{\text {th }}$ century Csaba Csorba dated the fall of the fort to 1529, when Suleiman was on a quest against Vienna and, on his way back, took Bač. The famous Osmanologist Előd Vass believed that Turks took Bač in 1541 after they had taken Buda (Vass 1979: 9). Another famous Hungarian Osmanologist Ferenc Szakály believed that the fort of Bač fell between the spring and autumn of 1542. Historian Klára Hegyi, who researched the history of Bač, thinks that Szakály's theory is the best, i.e. that Bač fell into the Turkish hands in 1542. The said historians who think that the fort fell in 1529 rely on Szalahazi's letter from January 1529, who says that the Serbian defenders of Bač surrendered the fort without a fight to Turks. However, another source speaks against 1529, a Christian spy who enumerates all the forts that fell under the Turkish rule, but he does not mention Bač. Szakály and Hegyi (Hegyi 2007: 929) rely on another source which claims that Bač fell in 1542. The source from 1543 says that queen Isabella paid the Christian garrison in Bač: "Eorum officium erit custodire cum hoc equitum et peditum numero tum civitatem Zegedinum ac arcem Bachiensem, tum partes illas universas." (Szakály 1995: 467).

${ }^{52}$ Reiszig 1909: 96.

${ }^{53}$ Sekulić 1978: 69.

${ }^{54}$ Györe 2014: 123.
} 
Bač and Kalocsa, Archbishop Frangepán Ferenc, who was appointed by János Szapolyai in $1528 .^{55}$ The town seemed to have survived the impact of the quests from 1526 and 1529 , since Miklós Olah ${ }^{56}$ in his work "Hungaria" from 1536 wrote that Bač was the second centre of the archbishop of Kalocsa and that the town surroundings were fertile and rich in fish:

\begin{abstract}
Afterwards comes Bač, which is the second center of the Archbishop of Kalocsa, rich in everything, especially fish. I heard from honest people that around Bač you can get thousands of pike and carp, which are the size of a röf $(r e f)^{57}$ for one gold... The surroundings of Bačka are a plain and there are many towns, much wheat, many vegetables, etc. which are beautiful. Horses stand out in speed and endurance. Residents drink wine from Srem. ${ }^{58}$
\end{abstract}

\title{
2. Bačka during the Ottoman rule
}

The crown lands of Saint Stephen were divided into three parts and the central part was given to the Ottomans in 1541 after the occupation of Buda. Thus began relatively calmer times (1541-1552) when the Turks built their administration in their part of Hungary. As far as administration goes Bačka belonged to the Szeged Sanjak ${ }^{59}$ and it was divided into six nahiye, ${ }^{60}$ which were: Baja, Szeged (Segedin), Subotica (Szabadka), Sombor (Zombor), Bačka and Titel. Of course, the Ottoman conquests had far-reaching consequences in the demographic, religious, cultural and economic sense. Instead of the Hungarian Catholic population, who on the one hand were killed and on the other hand escaped, Orthodox Serbs settled this area. ${ }^{61}$

In economic terms, the Ottomans took care that the were taxes collected and they were conducted on the basis of the population census, i.e. they were determined on the basis of production conditions. Therefore, it was in their interest to retain the production forces of the occupied territory as this ensured the viability of their organization. ${ }^{62}$ In spite of this, the former fruitful land farming declined and its place was taken by livestock trade. The economic situation of the population was further exacerbated by the supply of Turkish troops with food and the payment of taxes to the Christian authorities as well. ${ }^{63}$

Bač was located on the territory that was not far from similar centers of the nahiye administration: Titel, Sombor, Baja, Kalocsa, which had the same chances for development. They used small offices, the army and had the potential to develop and become military garrisons, business and civic centers, to become cities. If we analyze these centers according to the above mentioned aspects, we can say that Bač was the most developed town of all. It became a true Balkan-Turkish town in the southern zone of the Ottoman occupied territory,

\footnotetext{
${ }^{55}$ Reiszig 1909: 96.

${ }^{56}$ Miklós Olah was born in Sibiu in 1493 and died in Bratislava in 1568. He was a bishop of Ostrogon, a humanist, and a historian. His most famous work was "Hungaria," a travelogue about the Hungarian kingdom.

${ }^{57}$ A Hungarian unit of measurement from the $16^{\text {th }}$ century. One ref is $62.2 \mathrm{~cm}$ long.

${ }^{58}$ Szamota 1891: 536.

${ }^{59}$ Rokay, Györe, Pál, Kasaš 2002: 198.

${ }^{60}$ The smallest administrative unit in the Ottoman Empire.

${ }^{61}$ R. Várkonyi 1987: 155.

${ }^{62}$ Káldy- Nagy 2008: 7.

${ }^{63}$ Szakály 1981: 59-74.
} 
whose population was completely different from the medieval population. ${ }^{64}$

\title{
3. The first Christian invasions
}

Although Turkish territories in Hungary were the northern defense lines of Islam, they never became parts of the empire, such as the Balkan or Anatolian wilayah. ${ }^{65}$ This is probably the reason why Christians repeatedly invaded the central and southern territories of former Hungary. A Hungarian Osmanologist Szakály Ferenc was the first to expose the theory of double taxation. He showed that the Christian troops had visited these territories long before the Long War (1591-1606). ${ }^{66}$

From historical sources we know that the first invasions occurred as early as the end of the 1540s. In 1549 the inhabitants of Szeged, Sremski Karlovci, Petrovaradin and the surrounding places complained and sought protection from Eger knights, who entered deep into the Ottoman territory and tried to expand their domination. However, these troops did not just rob the villages of the Bačka County. This was confirmed by the example of Magyar Miklós from 1550. Magyar was caught when he invaded the territory of the Szeged sanjak with 35 hussars and required taxes and carriages from the population of the Kalocsa nahiye for the needs of the Eger fortress. ${ }^{67}$ From the letter of Antun Verančić from 1567 we can learn more about this invasion:

\begin{abstract}
Sultan Selim hastens to stop the double taxation of the subjugated villages since the Hungarians have so far freely travelled along the bank of the Danube to Srem and Titel on the other side of the Tisza, and from there to Bač and Kalocsa, to loot and (as he says) oppress the serfs his father acquired with their threats. ${ }^{68}$
\end{abstract}

We can find similar news in a letter from the pasha of Buda from 1576, in which he complains that "the royal troops invaded and went all the way to Titel and they also robbed the city of Bač." 69

\section{The period of the Long War (1591-1606)}

The Long War was the first modern war of Hungary which lasted from 1591 to 1606 and was called the Fifteen-Year War or the Long War. The Habsburg Monarchy and the Ottoman Empire did not try to be victorious in one campaign, but they fought with a large army, year after year, on the fronts in Hungary and Erdély trying to win the final victory. ${ }^{70}$ The war inflicted enormous damage, ranging from the winter stays of the Turkish-Tatar

\footnotetext{
${ }^{64}$ Hegyi 2002: 200.

${ }^{65}$ Pasalik (wilayah, elajet, beylerbeylik) is the biggest administrative unit in the Ottoman Empire. Several sanjaks comprised a pasalik, which was ruled by a pasha. During the Turkish rule the conquered territories in Hungary were divided into six pasalik (Buda, Eger, Kanije, Timisoara, Varad and Uyvar).

${ }^{66}$ Szakály 1981: 44.

${ }^{67}$ Ibid. 52.

${ }^{68}$ Szilágyi 1850: 132.

${ }^{69}$ Takáts, Eckhart, Szekfü 1915: 103.

${ }^{70}$ Pálffy 2009: 102-103.
} 
army, through the robbery of imperial-royal troops to the destruction of entire settlements, resources and products. To make the situation even worse, diseases and hunger were raging so the number of population dropped dramatically in war zones. The consequences were far-reaching and for centuries affected the further development of Hungary. However, in the meantime neither warring party could significantly change the borders. ${ }^{71}$ This was not the first case that one superpower wanted to improve its situation by war, but it was all in vain. ${ }^{72}$

At that time the Ottoman state was in a crisis because they were paying a large army, but also due to the collapse of the monetary and tax system, population growth and waging a war against the Persians. ${ }^{73}$ For these reasons we can safely say that the empire sought a solution to the crisis by entering the war that spread throughout Hungary since $1593 .{ }^{74}$ The Ottoman troops in Bosnia and Hungary could barely wait for looting expeditions. The Bosnian pasha Hasan Predojević did everything he could to expand the conflict to a larger territory. In 1591 the Turks occupied Zalakomar (Zalakomár) ${ }^{75}$ and next year they took a fortress in Bihać, which was important in the line of defence of the Croatian military border. These sieges showed that it was impossible to avoid war. ${ }^{76}$

After the Turkish defeat at Sisak (22 June 1593), the Ottoman Empire declared war against the Habsburg Monarchy. The main goal was further occupation of Vienna. In order to achieve this, it was necessary to conquer fortresses along the Danube to secure a military path. In the war years of 1593 and 1594, the great Vizier Sinan achieved significant results in his campaigns. ${ }^{77}$ Using the Turkish strategy, which had been successful for centuries, they attempted to win over the noblemen of Hungary who had possession in the war zone, e.g. Ferenc Nádasdy, István Báthory and Ferenc Dobó. Turks tried to turn them into mercenaries, but they did not respond to calls. These decisions did not significantly affect the movement of the Turkish army, which occupied Veszprém and Palota in 1593 and Györ and the entire northern Danube in $1594 .{ }^{78}$ Vienna was in danger because only the fortress of Komárno remained in the hands of Christians. ${ }^{79}$

Despite the victories of the Ottoman army at the beginning of the war, they did not take advantage of these successes. In 1595 the Habsburg emperor Rudolf (1576-1612) made an alliance with the prince of Erdély Sigismund Báthory (1588-1594, 1594-1598, 1598 1599, 1601-1602) and began the counter-offensive of Christians. They won back Esztergom and Istvan Bocskai with the Prince of Wallachia won the victory over the Ottomans near Đurđevo in $1595 .^{80}$ The Erdély army besieged Timisoara for quite a long time, but unsuccessfully. ${ }^{81}$ In addition to the aforementioned famous quests of Christian, the troops

\footnotetext{
${ }^{71}$ Györe 2014: 129.

${ }^{72}$ R. Várkonyi 1999: 189.

${ }^{73}$ Brumett 2013: 55.

${ }^{74}$ Dávid 2013: 283-285.

75 Ibid

${ }^{76}$ Pálffy 2009: 103.

77 Tóth 2000: 64.

${ }^{78}$ Ágoston 1992: 66-67.

${ }^{79}$ Pálffy 2009: 104.

${ }^{80}$ Shaw 1976: 202.

${ }^{81}$ Tóth 2000: 66.
} 
also invaded the territory of present-day Vojvodina. ${ }^{82}$ The looting troops of the Duke of Erdély recruited by Serbs, Bunjevci and hajduks invaded in 1594/1595 the southern part of the Danube River basin, where the Christian armies did not move for quite some time and pillaged the country terribly. In spite of all this, the Turks managed to occupy new territories along the Croatian military border and south-western territories beyond the Danube. ${ }^{83}$

\section{The role of hajduks in southern invasions during the Long War}

Hajduks in Hungary were mainly cow herders, i.e. cattle herders who sold cattle to southern German and northern Italian cities, so they actively participated in the export of the Hungarian kingdom. In the history of hajduks in Hungary we can date the first crisis at the turn of the $15^{\text {th }}$ and $16^{\text {th }}$ centuries. Therefore, during the great peasant movement of 1514 hajduks became the base of recruiting for Dózsa György. The failure of the uprising could be seen as a failure to change the life of hajduks. We can freely say that hajduks needed a replacement of profession, so they became soldiers during the $16^{\text {th }}$ century, especially after the Ottoman conquests. During the struggle against the Turks the villages and towns were destroyed in Hungary, especially in the central and southern parts. When they lost their houses and small estates poor serfs and noblemen had to flee to Erdély or the Hungarian kingdom or they had to become soldiers and fight. Former cow herders became hajduks from the ranks of serfs and minor noblemen. ${ }^{84}$ The sources from that period called hajduks the fear for the Turks. ${ }^{85}$ The battle quality of hajduks was acknowledged by the famous military commander Giorgio Basta, who wrote in 1597 that hajduk troops fought against the Turks with such force and that he had never seen such determination anywhere else. ${ }^{86}$

An Ottoman historian İbrahim Peçevi ${ }^{87}$ from 1595 complained in his letter about the mercilessness of hajduks, whose numbers were so great that they were on the whole territory of the Buda pashalik:

\footnotetext{
The other problem is that of all ordinary people, no matter how many strong boys there were, everyone has become a hajduk so that one could not go from one town to another unless there were 500 to 600 people together. Also, no matter how many towns and fortresses there were, they were all plundered, Zemun across from Belgrade was burned down twice, Belgrade mills had to pay kharaj and fortresses and cities were besieged from Buda to Belgrade so no one could move from one place to another. In Pecs even I took the sword and the gun and lay there, in our poor house, after the sunset. All in all, the source of the problem was that they did not protect the borders, i.e. people. ${ }^{88}$
}

\footnotetext{
${ }^{82}$ Zirojević 2008: 130.

${ }^{83}$ Reiszig 1909: 108 .

${ }^{84}$ Rácz 1969: 14-20.

85 Tóth 2000: 22.

${ }^{86}$ Veress 1909: 16.

${ }^{87}$ An Ottoman historian born in Pécs around 1574. On his mother's side he was a descendent of a famous family of Sokolović. He worked as a clerk in different provinces of the empire. He spent most of his life in Hungary and participated in the Long War, e.g. in the siege of Ostrogon in 1595. After he retired in 1640 he became interested in historiography. His most famous work is Tarih-iPeçevi, whose two volumes cover the period from 1520 until 1640 (Fodor 2012: 143-145).

${ }^{88}$ Karácson 1916: 113-114.
} 
Unfortunately from this Peçevi's text we can not find out which fortresses and cities were besieged but it is very likely that they reached Bač and the surroundings travelling along the Danube.

\section{Ottoman and Tatar winter stays in part of the Ottoman Hungary}

During the Long War, the Ottomans also used Tatar troops. ${ }^{89}$ However, Tatars spent only four winters in Hungary. During these winters they also had robbing expeditions, primarily to supply Turkish fortresses with food..$^{90}$ They spent the winter of $1597 / 1598$ near Sombor, from where they led devastating robberies at great distances. Since this winter the cities near the Tisza and in the Great Plain had to welcome the Tatar troops. ${ }^{91}$ Turkish-Tatar troops also looted in the southern parts except in the vicinity of Buda during the year 1598 . The Tatar Khan then spent a winter in Sombor and continued his robbery in spring. ${ }^{92}$

Turkish troops also sometimes spent a winter in the Turkish part of Hungary. From the notes of Kâtip Çelebi ${ }^{93}$ we know that "the great vizier came to Buda and stayed there for seven days... Sombor and Bač were security for the left wing and Prizren and Mardin for the right wing." 94 We can learn from Josef von Hammer's book that Asian troops were sent to Asia Minor before winter, while the cavalry spent the winter in the southern cities of Ottoman Hungary - in Pecs, Bač, Osijek and Sombor. ${ }^{95}$ A contemporary and an eyewitness to a greater or lesser extent, Topçular Kâtip states the following in connection with the winter stays of Asian troops: "It was ordered that the beylerbeyi of Anatolia spend the winter in Bačka, Szeged and Sombor..." 96 These troops in the southern provinces were attacked by the companies of hajduks, which was written about in Ottoman sources as well.

\section{The march of hajduks and the royal army in the last years of the war}

Although Christians managed to defeat the Ottomans near Đurđevo in $1595,{ }^{97}$ the Ottoman army won the greatest battle of the Long War with Mezőkeresztes in $1596 .{ }^{98}$ However, the hajduks continued their robbing expeditions. In the last years of the Long War,

\footnotetext{
${ }^{89}$ Dávid 2013: 296.

${ }^{90}$ Ivanics 1994: 163.

${ }^{91}$ Hóman, Szekfü 1935: 425.

${ }^{92}$ Ivanics 1994: 167-168.

${ }^{93}$ His real name was Mustafa bin Abdulah, but he was best known under the name Kâtip Çelebi. He was born in 1609. He was a pilgrim who went to Mecca and he got the name Kâtip since he was a clerk in the Ottoman accounting. He is a famous historian, philosopher, theologist, mathematician and geographer. After his studies, around 1622, he got a job in the Anatolian army as a military clerk and travelled a lot with the army, so he was able to study the countries where the Ottoman soldiers went. Of all of his works we know 14, five of which are historical in character. Kâtip Çelebi was a careful, serious historian who wrote critically. Unlike other Ottoman historians, he did not use vulgar and crude language and he rarely used the term infidel for Christians. Since he wrote in mid $17^{\text {th }}$ century he used different historical sources and was an excellent compiler.

${ }^{94}$ Karácson 1916: 232.

95 Hammer 1978: 135-140.

${ }^{96}$ Yilmazer 2003: 26.

${ }^{97}$ Uyar, Erickson 2009: 77.

${ }^{98}$ Setton 1991: 12. Tóth 2000: 227.
} 
the most important quests along the Danube towards the south ${ }^{99}$ were led by the best Hungarian military leader Miklós Pálfi ${ }^{100}$ By 1599 the surroundings of Buda and Pest had been so destroyed that the Turks had to provide the supplies for the army from the southern parts of the Ottoman Hungary. Hajduks and the šajkaš of Miklós Pálfi wanted to attack these transports on the Danube. Relying on different sources, we can say that they had three conflicts with Turks, which were very successful. ${ }^{101}$ After these successes Pálfi reorganized the army and planned new quests. Many hajduks responded to Pálfi's call because they were hoping for a rich loot. Pálfi divided the army into three parts that went in different directions. ${ }^{102}$

One military company went along the left bank of the Danube towards Kalocsa, Baja, Sombor and Bač. The aim of this campaign was to stop the Ottoman supply of Buda. ${ }^{103}$ They sent rich supplies to the north from Smederevo and Belgrade and the ships were accompanied by a serious army of 5000 soldiers. Hajduks made traps on the islands of the Danube along the way. ${ }^{104}$ According to Istvánfi, these islands were not far from Kalocsa:

They went not far from Kalocsa, where the Erdut fortress was located, which is now empty and ruined. In case an enemy army moves towards these parts of the Danube, they would attack them with the ships that supply this island. ${ }^{105}$

The fortress of Erdut was taken over by the hajduks. István Ileshazy ${ }^{106}$ wrote about the hajduks and their struggles:

They lived in the mountains of Baranja and Somogy and bravely fought against the pagans. They captured Erdut and many fortresses only with swords. The Turks of the Military Frontier gathered several times and went against them, however, they always lost to Turks. ${ }^{107}$

Ottomans knew that Christians frequently attacked their troops in these areas, so they often secured their own transport on the Danube with a substantial army. These land escorts were often defeated by the hajduks with their Slavic auxiliary troops and attacked the Turkish fleet. In 1599 we know specifically that this Turkish fleet had fifty eight ships, on

\footnotetext{
${ }^{99}$ Dankó 1967: 186-187.

${ }^{100}$ Miklós Pálfi, the "hero of Györ" (1552-1600) is one of the greatest Hungarian military leaders during the Long War. He was successful against the Turks on several occasions. He started his career by fighting the Turks in the 1570s and 1580s and was especially prominent in regaining Györ, Székesfehérvár and Veszprém. In an open battle at Romhány he defeated the Turks for the first time. This victory was psychologically important because he showed that Muslims were not undefeatable.

${ }^{101}$ Szentkláray 1917: 111.

102 Ibid. 113

103 Šmit 1939: 44.

${ }^{104}$ Szentkláray 1885: 112-114.

${ }^{105}$ Benits 2008: 325.

${ }^{106}$ István Ileshazy (1541-1609) was a Protestant nobleman, a grand župan and a palatine of Hungary from 1608 to 1609. He actively participated in István Bocskai’s uprising 1604-1606. His diary covers the period of Hungarian history from 1592 to 1603 .

${ }^{107}$ Kazinczy 1863: 76-80.
} 
which they transported grain, salted meat, biscuits and gun powder. ${ }^{108}$

Since the fortresses in the surrounding area were under the rule of the Ottomans (as well as the fortress of Bač), the hajduks could not even take away the captured loot with them, so they destroyed what they could not take away. After these events, the hajduks continued their quest towards the south and west. One part went to Osijek, where they were victorious over the Ottomans and destroyed a section of the Osijek bridge which was important for the Ottomans. The rest went to the region where the Serbian population lived and plundered there. ${ }^{109}$ From Miklós Pálfi's letter of 3 July 1599 we can learn about the activities of hajduks from that year: "The 2000 hajduks again attacked the Turks, of whom only 300 had fled. They occupied more fortresses... and they wanted to destroy all of them all the way to Belgrade." 110 Thanks to these victories over the Ottomans along the Danube hajduks managed to rob the region all the way to the mouth of the Tisza into the Danube (Titel), i.e. the surrounding area of the Tisza, sailing on the river to Bečej and plundering the towns in Bačka. ${ }^{111}$

Part of them robbed Sombor and Bač, even Bačka Palanka, which was then called Pest. The place was established only in 1593, but Christians took it and burnt it down in 1599. From Pálfi's letter from 1599 we can conclude that hajduks robbed the town: " 1600 hajduks divided the prey before the bey of Bačka." 112 If the company of robbers which was composed of the border guards collected a larger prey and captured more slaves, they would organize a division of prey or then so-called "kótyavetye, auctio, austeilung (Beautverkaufung)," as the border guards and Christian soldiers called it. They shared the prey (goods, cattle, property, and slaves) depending on the merits in the campaigns. The Hungarian name "kótyavetye" is derived from the Slavic term of who would offer more "ko će veće." From Pálfi's letter we can assume that the city was robbed and that the loot was divided among robbers. ${ }^{113}$ When they returned from this quest to Bačka, each hajduk received 1000 silver thaler. ${ }^{114}$

At the beginning of the $17^{\text {th }}$ century, the Ottomans could barely keep their territories and fortresses from the hajduks wandering and looting; had there not been for the Bocskai uprising in 1604, the Turks would starve to death, as Gábor Bethlen, the prince of Erdély, announced:

Since only I begged prince Bocskai to be faithful to the Emperor (Sultan)... the prince liberated the emperor's border houses, Timisoara (Temesvár), Čanad (Csanád), Gyula (Đula), Szeged, Bač, Szolnok (Solnok), Eger (Jegar), Hatvan, and smaller towns, whose gates were so attacked that the Turks could not even eat. ${ }^{115}$

\footnotetext{
${ }^{108}$ Szentkláray 1917: 114.

${ }^{109}$ Szentkláray 1917: 114.

${ }^{110}$ Marczali 1878: 907.

111 Szentkláray 1885: 115.

${ }^{112}$ Marczali 1878: 907.

${ }^{113}$ Pálffy 1997: 25-26.

114 Marczali 1878: 907.

${ }^{115}$ Szilágyi 1879: 440.
} 
We can read in Kâtip Çelebi's work that the Turks tried to defend their fortresses so "the Islamic army dragged four large cannons, two of which they left in Sombor and two in Bač, and then quickly crossed the Petrovaradin bridge and entered Belgrade." 116

It is important to mention that, according to Istvan Ivanyi, the hajduks managed to take the fortress of Bač on 12 September $1604^{117}$ and this claim was confirmed by a chronicle from Sárospatak (Šarospatak), which says: "On 12 September, the Hungarians left Bač in front of the commanding pasha blowing up everything and leaving desolation behind." 118 However, this piece of information is quite debatable because Ferenc Toldy, who published the chronicle in 1857, said that there was a mistake and that instead of Bač the Turks took Pest across the road from Buda so "under 12 September Pest should put instead of Bač." 119 After we have conducted research we came to the conclusion that Ferenc Toldy read the chronicle from Sárospatak well and that Istvan Ivanyi had misinterpreted the historical source. ${ }^{120}$

According to Klára Hegyi, who wrote about the Turkish fortress and the crew of the fortress in Hungary, in 1604 the number of the crew of the fortress of Bač increased. The number of the crew was the largest in the history of Turkish Bač. From these data we noted that the fortress was attacked and therefore the crew in the fort was increased. ${ }^{121}$ We can also not neglect the fact in the book Military History of Hungary by József Borus, with the historical map of the Long War and the Battle of Bač marked on it. The conclusion would be that we should not deny that hajduks reached Bač and that there was a clash between Christians and Muslims. ${ }^{122}$

\section{The consequences of the Long War in the history of the Szeged sanjak}

During the Long War the Turkish quests and Turkish and Tatar winter stays had a devastating influence, especially on those territories where Hungarians mostly lived. In the medieval Hungarian kingdom Hungarians accounted for $75-80 \%$ of the population and mostly lived in the central part of the country in large areas and hilly territories, as well as on the eastern and northern peripheries along the rivers. ${ }^{123}$ This statistics was getting worse for the Hungarian population since the year 1526 when Hungarians escaped and other population, mostly Serbs, Bunjevci and Šokci, moved to their place on the territory of the former Bačka, Bodroš and Csanad Counties. ${ }^{124}$

During the Turkish conquest (1526-1541, 1541-1568) the Hungarian population and the network of settlements were capable of regeneration and survived these difficult

\footnotetext{
${ }^{116}$ Karácson 1916: 349.

${ }^{117}$ Iványi 1907: 14.

118 Toldy 1857: 47.

${ }^{119}$ Ibid. 47.

${ }^{120}$ Iványi 1900: 58-59.

${ }^{121}$ Hegyi 2007: 932-933.

122 Borus 1984: 220.

${ }^{123}$ Pálffy 2000: 172-173.

${ }^{124}$ Szakály 1991: 11-18.
} 
times, ${ }^{125}$ but in the period of the Long War, especially since 1593 when the country became a front between the two great powers, they could no longer oppose the periodic destruction and desolation. During the Long War, the number of the population of Bačka dropped drastically. ${ }^{126}$ The constant war, the immigration of the Slavic population, the quests of hajduks and Tatars reduced the Hungarian population. ${ }^{127}$ In the $1540 \mathrm{~s}$ and 1550 s, when the county of Bač and the towns of Sombor and Bač and their surroundings were used for supplying the fortress of Eger, common people lived on granges, which meant that they were semi-nomads. The delegates of the Buda pasha mentioned a few people who were engaged in land farming. They were taken to Buda and these parts, i.e. "Bačka was described as a desert." 128

The Long War ended in peace in Zsitvatorok (Žitvatorok) in 1606. In the last years of the war, war operations were led in the north, not in the south. ${ }^{129}$ After 1604 hajduks, who fought against the Turks, fought in the army of Bocskai against the Habsburgs. After the end of Bocskai's uprising in 1606, István Bocskai granted deeds of donations to hajduks. After the Long War, no serious fighting took place until the 1660 s. ${ }^{130}$

\section{SOURCES:}

Gévay, A. von. Urkunden und Aktenstücke Geschichte Der Verhältnisse Österreich, Ungern Und der Porte Im XVI. und XVII. Jahrhunderte.I Wien: Strauss, 1840.

B.Szabó, J. Mohács. Budapest: Osiris, 2006.

Benda, K. A Bocskai szabadságharc, Budapest: Művelt Nép Könyvkiadó, 1955.

Benits, P. Istvánffy Miklós magyarok dolgairól irt históriája Tállyai Pál XVII. századi fordításában, Budapest: Balassi Kiadó, 2008.

Karácson, I. Török történetírók III. Budapest: MTA, 1916.

Kazinczy, G. Gr. Illésházy István nádor följegyzései 1592-1603, Monumenta Hungariae HistoricaMagyar Történelmi Emlékek II. Pest: MTA, 1863.

Katona, T. Mohács emlékezete. Budapest: Magyar Helikon, 1976.

Marzali, H. (szerk.) (1878): Regesták a külföldi levéltárakból. Budapest, Magyar Történelmi Társulat.

Szamota, I. Régi utazások Magyarországon és a Balkán-félszigeten 1054-1717. Budapest:FranklinTársulat, 1891.

Szilágyi, S. Verancsics Antal összes munkái V. Monumenta Hungariae Historica. Magyar Történelmi Emlékek VI. Pest: Akadémiai kiadó, 1850. . Bethlen Gábor Erdélyi fejedelem kiadatlan politikai levelei, Budapest: MTA, 1879.

Sremac, Đ. Poslanica o propasti Ugarskog kraljevstva= GeorgiiSirmiensis, Epistola de perditioneregniHungarorum, Beograd: Srpska Književna Zadruga, 1987.

Thúry, J. Török történetírók I. Budapest: MTA, 1893. . Török történetírók II. Budapest: MTA, 1896.

Veress, E. Basta György hadvezér levelezése és iratai (1597-1607) I-II, Budapest: MTA, 1909.

${ }^{125}$ Györe K. 1973: 175-176. Stelzer F. 1885: 14-27.

${ }^{126}$ Rokay, Györe, Pál, Kasaš 2002: 450.

${ }^{127}$ Szakály 1997: 153.

${ }^{128}$ Hóman, Szekfü 1935: 428.

${ }^{129}$ Györe 2014: 129.

${ }^{130}$ Szakály 1990: 181. 


\section{REFERENCES:}

Ágoston, G. A hódolt Magyarország, Budapest: Adams Kiadó, 1992.

Barta, G. A Sztambulba vezetö út 1526-1528, Budapest: Magvető Kiadó, 1983.

Borus, J. Magyarország hadtörténete I, A honfoglalástól a kiegyezésig, Budapest: Zrínyi Kiadó, 1984.

Brummett, P. 'Ottomanexpansionin Europe' in: Suraiya N. Faroqki (ed.): The Cambridge History of Turkey II. Cambridge: Cambridge University Press, 2013, 44-74.

Ćirković, S. 'Ostaci državnog života u doba turske prevlasti. Poslednji despoti' in: Jovanka Kalić (ed.), Istorija srpskog naroda II. Beograd: Srpska književna zadruga, 1982. (Serbian Cyrillic)

Dankó, I. 'A délvidék és a hajdúk' in: Dankó I. (ed.), Janus Pannonius Múzeum Évkönyve, Pécs: Janus Pannonius Múzeum, 1967, 179-189.

Dávid G. 'Magyarország népessége a 16-17. században' in: Kovacsics J. (ed): Magyarország történeti demográfiája (896-1995). Millecentenáriumi elöadások. (Szerk. Kovacsics József). Budapest: Központi Statisztikai Hivatal, 1997, 141-171.

. Pasák és bégek uralma alatt, Budapest: Akadémiai Kiadó, 2005.

. Ottomanarmies and warfare, 1453-1603' in: Suraiya N. Faroqki (ed.), The Cambridge History of Turkey II, Cambridge: Cambridge University Press, 2013, 276-320.

Dudás, Gy. A szabad hajdúk története a XVI. és XVII. században, Szeged: Engel Adolf, 1887.

. Bács-Bodrogh vármegye egyetemes monográfiája. I. Zombor, Bittermann Nándor Könyv-és Könyomdája, 1896.

Érdújhelyi M. 'Magyarország vármegyéi és városai. Újvidék története' in: Borovszky S. (ed.), BácsBodrog vármegye I, Budapest: Légrády testvérek könyvnyomdája, 1909, 237-272.

Fodor, P. 'Egy pécsi származású oszmán történetíró: Ibrahim Pecsevi’ in: Szakály F., Vonyó J. (ed.), Pécs a hódoltság korában. Tanulmányok (Pécsi Mozaik 2.), Pécs: Kronosz Kiadó, 2012, 142168.

Györe, K. 'Bácska népességszáma a XVI. század végén. Történeti népességstatisztikai vizsgálat' in: Rehák L. (ed.), Létünk, 2-3, Újvidék: Forum Könyvkiadó Intézet, 1973, 171-177.

Györe, Z. 'Ratovi i stanovništvo Ugarske 1521-1718', Istraživanja, 25, Novi Sad, 2014, 119-137.

Hammer, J. Historija Turskog carstva II, Zagreb: Elbookers, 1978.

Hegyi K.'A török Bács' in: Fodor P., Pállfy G., Tóth István Gy. (ed.), Tanulmányok Szakály Ferenc Emlékére, Budapest: MTA TKI, 2002, 199-213.

. A török hódoltság várai és várkatonasága I-III, Budapest: História, 2007.

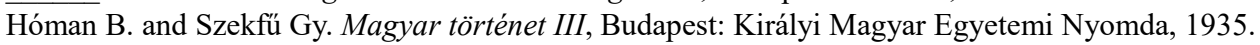

Ivanics, M. A Krími Kánság a tizenöt éves háborúban, Budapest: Akadémiai kiadó, 1994.

Iványi, I. ' Bács II. Krónika'. in: Roediger L. (ed.), A Bács- Bodrogh Megyei Történelmi Társulat Évkönyve XVI. II, Zombor: Bittermann Nándor és fia Könyv- és Kőnyvnyomdája, 1900, 51-66. . Bács-Bodrog vármegye történeti-földrajzi helynévtára III, Szabadka: Szabados Sándor Könyvnyomdája, 1907.

Káldy-Nagy, Gy. A Szegedi szandzsák települései, lakosai és török birtokosai 1570-ben, Szeged: Csongrád Megyei Levéltár, 2008.

Kirmizi A. 'Topçular Kâtibi Abdülkādir (Kadrî) Efendi Tarihi' in: Yilmar Z. (ed.), Türk Tarih Kurumuyayınları, III/21, Ankara, 2003, 26.

Pálffy, G. 'Rabkereskedelem és rabtartás Magyarországon' in: Pesti M. (ed.), FONS, 10, Budapest: Fons Alapítvány, 1997, 5-78. . A tizenhatodik század története. Budapest: Pannonica kiadó, 2000. . A három részre szakadt ország 1526-1606. Magyarország története 9. Budapest, Kossuth kiadó, 2009. 
R. Várkonyi Á.'Magyarország története 1526-1686', in: PachZs. (ed.), Magyarország története tíz kötetben, Budapest: Akadémiai kiadó, 1987.

. Három évszázad Magyarország történetében I. Budapest: Korona kiadó, 1999.

Rácz, I. 'A hajdúk a XVII. században' in: Rácz I. (ed.), Magyar történeti tanulmányok II, Debrecen: KLTL, 1969, 5-24.

Reiszig, E. 'Magyarország vármegyéi és városai. Bács-Bodrog vármegye története' in: Borovszky $\mathrm{S}$. (ed.), Bács-Bodrog vármegye II, Budapest: Légrády testvérek könyvnyomdája, 1909, 28-248.

Rokay, P. Györe, Z. Pál, T. Kasaš A. Istorija Mađara, Beograd: Clio, 2002. (Serbian Cyrillic)

Šmit, R. 'Iz prošlosti Bača'. Glasnik istorijskog društva u Novom Sadu, 37-38, 1939, 382-413. (Serbian Cyrillic)

Szakály, F. Magyar adóztatás a török hódoltságban. Budapest: Akadémiai kiadó, 1981. . Virágkor és hanyatlás 1440-1711, Budapest: Háttér Lap-és Könyvkiadó, 1990.

. 'Szerbek Magyarországon - szerbek a magyar történelemben' in: Zombori I. (ed.), A szerbek Magyarországon, Szeged: Móra Ferenc Múzeum, 1991, 11-48.

. 'Szeged török uralom alá kerülésének történetéhez' in: Koszta L. (ed.), Kelet és nyugat között. Történeti tanulmányok Kristó Gyula tiszteletére. Szeged: Szegedi Középkorász Mühely, 1995, 451-169.

. Magyar intézmények a török hódoltságban, Budapest: MTA, 1997.

Sekulić, A. Drevni Bač, Split: Zbornik Kačić, 1978.

Setton K. M. Venice, Austria, andtheTurks in the Seventeenth Century, Philadelphia: Independence Square, 1991.

Szentkláray, J. A dunai hajóhadak története, Budapest: MTA, 1885.

Shaw, S. History of the Ottoman Empire and modern Turkey I. Empire of the Gazis: The rise and decline of the Ottoman Empire, 1280-1808, Cambridge: Cambridge University Press, 1976.

Stelzer F. 'Bácskai adatok a török defterekben' in: Margalits E. (ed.), A Bács- Bodrogh Megyei Történelmi Társulat Évkönyve I, III/IV, Zombor: Bittermann Nándor Könv- és Könyvnyomdája, $1885,14-27$.

Stojkovski, B. 'Saradnici Jovana Nenada' in: Đ. Sladoje (ed.), Trag III. VII, Vrbas: Narodna biblioteka „Danilo Kiš“،, 2007, 149-163. (Serbian Cyrillic)

Tóth, S. L. A mezökeresztesi csata és a tizenöt éves háború, Szeged: Belvedere, 2000.

Uyar, M. Erickson, J. E. A Military history of the Ottomans. From Osman to Attatürk, Santa Barbara: ABC-Clio, 2009.

Vass, E. 'A szegedi és a csongrádi náhije 1548. évi török adóösszeírása' in: Farkas J. (ed.), Tanulmányok Csongrád megye történelméböl III, Szeged: Csongrád megyei Levéltár, 1979, 580.

Zirojević, O. Turci u Podunavlju I, Pančevo: Istorijski arhiv, 2008. 


\title{
АТИЛА ПФАЈФЕР \\ Универзитет у Новом Саду, Филозофски факултет, Одсек за историју \\ БОРБА ХРИШЋАНА ПРОТИВ ОСМАНЛИЈА НА ЈУГОЗАПАДУ БАЧКЕ ОД МОХАЧКЕ БИТКЕ ДО ЖИТВАТОРОЧКОГ МИРА
}

\begin{abstract}
Резиме
После пораза угарске војске на Мохачком пољу, Угарска је доживела можда најтежу епоху у својој историји. У исто време морала се борити против освајача, а у међувремену отворено је и питање престолонаследника због погибије Лајоша II Јагелонца у Мохачкој бици. Угарска је била подељена на два табора у вези са питањем ко ће бити нови краљ. Док су велики магнати и племство на северу и на западу изабрали надвојводу Фердинанда Хабсбуршког за краља, угарски племићи на средишњим и источним деловима земље су изабрали ердељског војводу Јаноша Запољу. Међутим, већи проблем од тога био је што је Угарска у наредних скоро два века била бојиште између Османског царства и Хабсбуршке монархије. После османског похода из 1526. године видело се коју штету и пустошење су оставили освајачи иза себе. Бачка жупанија, која је била густо насељена и привредно богата, постала је пустиња. Крунске земље Светог Стефана су биле подељене на три дела и централни део је припао Османлијама 1541. године после окупације Будима. Што се администрације тиче Бачка је припала Сегединском санџаку и била је подељена на шест нахија, које су биле: бајска, сегединска, суботичка, сомборска, бачка и тителска. Наравно, османска освајања су имала далекосежне последице на демографском, верском, културном и привредном пољу. За време турских освајања (1526-1541, 1541-1568) мађарско становништво и мрежа насељених места су биле способне за регенерацију и преживели су ова тешка времена, међутим, период Дугог рата, посебно од 1593. године, када је земља постала фронт између две велесиле, нису могли више да се супротставе периодичним уништавањима и харањима. За време Дугог рата турски походи, турска и татарска зимовања су утицала врло разарајуће, посебно на оне територије где су живели већином Мађари. У средњовековној Угарској краљевини Мађари су чинили 75-80 \% становништва и махом су живели у средини државе на великим површинама и брежуљкастим територијама, на источним и северним периферијама уз реке. Ова статистика је била све лошија за мађарско становништво од времена после 1526. године кад је мађарско становништво побегло, а на његово место се доселило словенско становништво, махом Срби, Буњевци и Шокци на територијама некадашње Бачке, Бодрошке и Чанадске жупаније.У периоду Дугог рата број становништва Бачке је драстично опао. Константни рат, усељавање словенског становништва, пљачкашки походи хајдука и Татара смањили су мађарско становништво.
\end{abstract}

Кључне речи: рана модерна историја, Османлија, Османска Угарска, Бачка и Бодрошка жупанија, Бачка тврђава, турски ратови, војна историја.

(C) Faculty of Philosophy, Novi Sad, 2017

ISTRAŽIVANJA - JOURNAL OF HISTORICAL RESEARCHES 28, 86-104 